\title{
HABERMAS: DA ANÁLISE DA ÖFFENTLICHKEIT AO PROJETO DE UMA “TEORIA DO AGIR COMUNICATIVO"
}

RESUMO: Este artigo pretende ser uma exposição da Filosofia do Esclarecimento de Habermas Nesse sentido, apresentaremos especialmente seu pensamento inicial, com o escopo de estabelecer seus fundamentos, o que implica iniciar com as influências sobre ele (I. Kant, J. L. Austin, o "segundo" Wittgenstein, M. Weber, E. Husserl, K. O. Apel, entre outros), assim como com sua crítica aos primeiros membros da Escola de Frankfurt (especialmente contra o pessimismo de T. Adorno e M. Horkheimer acerca da possibilidade de a razão nos libertar). Finalmente, mostraremos como Habermas é uma extensão do projeto de uma Filosofia do Esclarecimento, o que faz dele um exemplo do pensamento moderno na história contemporânea da Filosofia.

PALAVRAS-CHAVE: Esclarecimento. Ética. Pragmática.

Introdução: Habermas e a ideia de publicidade (Öffentlichkeit)

O primeiro passo de Habermas em direção ao conceito de "publicidade" (Öffentlichkeit) ocorre em sua Habilitationschrift, intitulada, precisamente, Strukturwandel der Öffentlichkeit. Untersuchungen zu einer Kategorie der bürgerlichen Gesellschaft, de 1962. Nessa obra encontramos, ainda, uma forte influência de seus predecessores da Escola de Frankfurt, Theodor Adorno e Max Horkheimer. Tal influência fica manifesta na ideia

1 Professor do Departamento e do Programa de Pós-Graduação em Filosofia da Universidade Federal de Pelotas (UFPel). http://www.ufpel.edu.br/ich/ppgfil/index.htm. E-mail: ferrazca@hotmail.com 
consoante a qual a "publicidade" foi conduzida por interesses corporativistas, manifestos na concepção de uma "sociedade totalmente administrada". Esta representaria a bem sucedida aliança entre o poder político e a economia, a qual geraria, por fim, uma espécie de "manufacturing consent".

No entanto, também nessa obra já encontramos uma perspectiva que afasta Habermas de seus predecessores: Habermas, diferentemente de Adorno e Horkheimer, está preocupado em recuperar os princípios liberais que vigem em uma sociedade democrática (em oposição a toda forma de totalitarismo). Nesse sentido, para o projeto de Habermas, o conceito de "publicidade" mostrou-se valioso. Apesar de manipulado por interesses corporativistas, ele mantinha um, digamos, "potencial esclarecedor". Ele poderia ser o locus fundacional de uma sociedade baseada em princípios democráticos. Assim, a despeito do diagnóstico dos primeiros autores da Escola de Frankfurt, o espaço da "publicidade" (da "esfera pública"), seria, também, um espaço para a reforma, para a transformação. Dessa forma, a perspectiva de Adorno e Horkheimer seria unilateral: eles teriam sido incapazes de perceber o "outro lado" da "esfera pública", o que os teria impedido de reconhecer o papel desta na fundação de uma sociedade democrática (e não mais "totalmente administrada").

Com efeito, isto ainda não é defendido explicitamente em Strukturwandel der Öffentlichkeit. Untersuchungen zu einer Kategorie der bürgerlichen Gesellschaft. Afinal, vários acontecimentos que tiveram palco na década de 1960 (como a "contracultura", por exemplo, bem como o feminismo, os movimentos civis em defesa do direito das "minorias", a revolução cubana, os protestos contra a Guerra Fria e a guerra do Vietnã, reações estudantis ao autoritarismo estatal etc.) dariam conteúdo às reflexões posteriores de Habermas. Tais eventos devem ter mostrado a Habermas que poderíamos aprender com nossos erros, isto é, que seria possível sair, via entendimento (Verstandingung) daquele estado desolador descrito por Adorno e Horkheimer.

Assim, ainda que Habermas descreva, em sua Habilitationschrift, a transformação e aniquilamento, nos séculos XIX e XX, daqueles ideais de "publicidade" engendrados no século XVIII, na Inglaterra, França e Alemanha, ele investiga a possibilidade daqueles mesmos ideais em uma sociedade pós-liberal. O projeto é ousado. Trata-se de pesquisar a possibilidade de um ideal de "publicidade" engendrado em um contexto muito distinto daquele do século XVIII, no qual o cenário político, econômico e cultural era deveras diferente. Em outras palavras, como resgatar o ideal de uma "esfera pública" na qual podem ser engendrados os ideais de uma sociedade democrática, em um ocidente distinto daquele em que tal conceito foi, pela primeira vez, trazido a lume? 
Em Strukturwandel der Öffentlichkeit. Untersuchungen zu einer Kategorie der bürgerlichen Gesellschaft, fica claro que Habermas ainda não está totalmente desvinculado de seus predecessores da Escola de Frankfurt. No entanto, ele também não parece desposar a perspectiva derradeira daqueles. Ele já está em busca de uma alternativa para a situação descrita inclusive por ele, na referida obra. Porém, somente após essa obra ele estará em condições de levar adiante seu projeto. Ainda que um rompimento com Adorno e Horkheimer já possa ser observado em Strukturwandel der Öffentlichkeit. Untersuchungen zu einer Kategorie der bürgerlichen Gesellschaft, o rompimento radical se verá em obras posteriores.

Não obstante, um ponto central do texto de 1962 deve ser enfatizado: a história, para Habermas, permanece em movimento.

Com efeito, sua Habilitationschrift mostra-nos uma gênese do conceito de "esfera pública", a partir do século XVIII. Habermas investiga circunstanciadamente a origem e desenvolvimento dessa ideia, a qual será fundamental para seu próprio projeto vindouro.

Assim, em seus capítulos iniciais, a obra aborda, sobretudo, o surgimento e desenvolvimento da ideia burguesa de "esfera pública". Tratase, é-nos lícito sugerir, de uma reconstrução histórica desse conceito. Neles, Habermas aborda questão acerca de como foi possível os sujeitos (privados) chegarem a um acordo sobre questões públicas (com vistas à consecução de interesses particulares). Tal "solidariedade" foi motivada, especialmente, por um novo modelo econômico fundado em um novo sujeito, o "burguês liberal". Com isso, chegou-se a uma nova esfera, a "esfera pública", a qual assinalou o fim dos poderes feudais da Igreja e da nobreza (que até então determinavam a esfera pública, com vistas a interesses particulares - dessas instituições mesmas). Em decorrência, os indivíduos tornaram-se cônscios de sua autonomia, o que foi reforçado pelo desdobramento de formas midiáticas de comunicação, como jornais, por exemplo. O burguês encontrou, por conseguinte, veículos para expressar sua posição. Várias novas formas de associação deram azo à interação entre os indivíduos, o que contribuiu sobremaneira para a ampliação de uma nova esfera, a "esfera pública". Na filosofia, isso pode ser percebido em autores como John Locke, J. J. Rousseau e Immanuel Kant, entre outros. Temas tais quais "tolerância", "liberdade enquanto seguir uma lei que nós mesmos nos damos", "autonomia", "liberdade da pena", "liberdade de expressão", "Aufklärung" etc., são aspectos desse novo ideal.

Em suma, nesse ambiente, fomenta-se a discussão pública em torno de temas cujo interesse é tanto privado quanto coletivo. E, dado que todos têm voz, cabe a busca por um consenso que unifique as mais diversas 
posições. Nesse sentido, a "esfera pública" adquire um status normativo no seio do século XVIII. Essa inter-relação, Habermas a aponta mesmo na atividade literária. Ele menciona, por exemplo, os saraus literários, um típico fenômeno burguês. Neles, o sujeito revelava sua subjetividade diante do outro. Esse seria, segundo Habermas, um exemplo do privado ganhando publicidade. Isso representaria um aprendizado para que o indivíduo se tornasse capaz de expressar, agora publicamente, suas perspectivas particulares. Tal elemento exigiu igualmente o advento de normas discursivas, as quais passaram a determinar um novo tipo de sujeito (em uma nova concepção normativa de sujeito), um sujeito capaz de usar publicamente sua voz (com vistas à manifestação de seus pensamentos, sentimentos privados etc.). Aqui passa a viger, pois, uma nova forma persuasiva, não mais a tradição ou a autoridade, mas a racionalidade. Desse modo, os mais variados temas passam a ser possíveis objetos de crítica. Mesmo assuntos delicados, envolvendo a autoridade da Igreja ou do Estado, por exemplo, passaram a ser tematizados: a esfera pública (burguesa) pôde colocar em debate temas até então inquestionáveis. E todos deveriam poder participar do debate. Com isso, Habermas chega, em sua abordagem da gênese da Öffentlichkeit, à conclusão de que esta se tornou um novo princípio normativo. Assim, com o passar do tempo a Öffentlichkeit tornou-se fonte de legitimidade em assuntos de interesse público. Conforme Habermas, o debate público deveria poder fazer com que a voluntas pudesse tornar-se ratio: o debate lograria alcançar o consenso (objetivo) a respeito daquilo que seria objeto de interesse de todos os cidadãos (subjetividades).

Segundo a análise de Habermas, não se trataria, aqui (no século XVIII), de uma disputa, o que viria, segundo ele, no século seguinte, com o desenvolvimento do liberalismo. No século XVIII, o surgimento da Öffentlichkeit envolveria o reconhecimento de valores e concepções comuns a todos os indivíduos, os quais seriam articulados discursivamente na "esfera pública", em uma busca por reconhecimento (e consenso). Em verdade, o burguês no século XVIII tinha por objetivo, reconhece Habermas, sobretudo, justificar sua ascensão política e econômica, sustentando a universalidade de sua pretensão. Isto, aliás, é algo que Habermas intenta manter, a saber, o respeito à alteridade baseado nas convicções compartilhadas.

Não obstante o aspecto louvável de tal empreendimento, nos dois séculos seguintes, tal ideia (de respeito à alteridade baseado em supostos interesses mútuos) foi colocada sob suspeita em virtude de podermos observar, historicamente, o contingente de excluídos dessa assim chamada "esfera pública". A partir de sua leitura de Karl Marx, Habermas reconhece a falácia envolvendo uma "esfera pública" caracterizada pela acessibilidade geral. Habermas percebe, pois, que tal "esfera pública" passa a ser palco 
apenas daquele sujeito caracterizado como "proprietário". O ideal abstrato de "humanidade" cai, assim, por terra. Dessa forma, o ideal de Öffentlichkeit mascarou outra acepção: a ideia de "esfera pública" enquanto locus para a manutenção do poder econômico e político.

No entanto, tal análise será valiosa para o projeto habermasiano. Habermas tentará resgatar precisamente a ideia basilar de Öffentlichkeit, qual seja, a ideia de que o processo discursivo no seio da "esfera pública" deve ser universalmente acessível. Portanto, embora reconheça a corrupção da ideia de "esfera pública", Habermas percebe a importância de mantermos o princípio de uma racionalidade discursiva acessível a todos. Dito de outra forma, Habermas reconhece, em sua análise, que, nos séculos XIX e XX, interesses privados passaram a dominar, parasitariamente, a "esfera pública", o que resultou na respectiva Strukturwandel, afastando-o do princípio originário da racionalidade discursiva com vistas ao consenso. Ainda tendo em mente sua leitura de Karl Marx, Habermas vê nessa Strukturwandel a lógica mesma do capitalismo com sua divisão de classes. Tal Strukturwandel implicou a ruína do espaço para um debate público motivado pela racionalidade discursiva. Em resumo, a assim chamada "esfera pública" passou a ser controlada por determinados grupos, com vistas à hegemonia econômica. O conceito de Öffentlichkeit perdeu seu sentido, tornando-se mero instrumento para a reprodução de certas relações de poder. Até esse ponto, Habermas está próximo de Adorno e Horkheimer e da primeira geração da Escola de Frankfurt, de uma maneira geral.

Malgrado esse diagnóstico, Habermas distancia-se de seus predecessores. Ele intenta, com efeito, recuperar a ideia de Öffentlichkeit. Assim, ele busca por aqueles elementos imanentes a tal racionalidade discursiva. Todavia, em Strukturwandel der Öffentlichkeit. Untersuchungen zu einer Kategorie der bürgerlichen Gesellschaft, ainda não encontramos uma solução para o problema que nela é exposto e desenvolvido. Será em seus escritos posteriores que Habermas logrará explicitar de forma sistemática (e mesmo positiva) o conceito de Öffentlichkeit. Com efeito, Habermas não abandona a ideia consoante a qual a burocracia imanente ao capitalismo é uma ameaça à esfera pública. Em seus escritos posteriores, ele reavaliará o jaez normativo da Öffentlichkeit. Não há dúvida de que elementos como a burocracia já mencionada, bem como a globalização, por exemplo, permanecem sendo ameaças à Öffentlichkeit. Contudo, em suas obras posteriores Habermas terá claro o aspecto, digamos, "esclarecedor" de certas manifestações, como a já referida "contracultura", os movimentos civis de uma maneira geral etc. Tais movimentos, que surgem no âmago das democracias liberais, abrem espaço para uma reavaliação da esfera pública enquanto esfera normativa. Dessa maneira, Habermas intenta ir além das 
meras considerações sociológicas (ainda que estas sejam, como veremos, fundamentais). Em suas obras posteriores, Habermas aprofundará, portanto, suas reflexões filosóficas, com vistas à uma fundamentação normativa de uma "teoria crítica da sociedade". Isso o levará, com efeito, à sua teoria do agir comunicativo.

Do projeto de uma reavaliação da esfera pública ao "diagnóstico" da modernidade: Habermas diante da questão: Was ist Aufklärung?

O projeto filosófico de "emancipação" não é novo. Na tradição filosófica, a primeira expressão notável (enquanto projeto filosófico) pode ser depreendida do célebre opúsculo de Immanuel Kant, intitulado Beantwortung der Frage: Was ist Aufklärung $?^{2}$ No texto de Kant, encontramos uma exortação à saída do estado por ele denominado de "menoridade" (Unmündigkeit), o qual é marcado notadamente pela preguiça (Faulheit) e pela covardia (Feigheit). Daí ele asserir, categoricamente: "Sapere aude! Tem coragem de fazer uso de teu próprio entendimento". Como é sabido, o projeto kantiano referente ao esclarecimento, sobejamente expresso no opúsculo supramencionado, caracterizava-se por ser uma tentativa de levar o homem à maioridade (Mündigkeit). Mas o que significaria sair daquele estado abjeto que Kant denominava menoridade? Seria o desenvolvimento de uma razão (tal como esta será denominada, a partir da obra de Adorno e Horkheimer) meramente "instrumental"? Obviamente não ${ }^{3}$. Todo desenvolvimento legítimo, como

\footnotetext{
${ }^{2}$ A caracterização do projeto kantiano se deixa perceber especialmente no primeiro parágrafo do texto suprarreferido (publicado em 1784, no Berlinische Monatsschrift), no qual afirma: "Aufklärung ist der Ausgang des Menschen aus seine r selbstverschuldeten Unmündigkeit. Unmündigkeit ist das Unvermögen, sich seines Verstandes ohne Leitung eines anderen zu bedienen. S e l b s t v e r s c h u l d et ist diese Unmündigkeit, wenn die Ursache derselben nicht am Mangel des Verstandes, sondern der Entschließung und des Mutes liegt, sich seiner ohne Leitung eines andern zu bedienen. Sapere aude ! Habe Mut, dich deines e i g e n e n Verstandes zu bedienen! ist also der Wahlspruch der Aufklärung" (KANT, 2004).

${ }^{3}$ Sobre uma crítica à "razão instrumental", diz-nos Horkheimer: "Tendo cedido em sua autonomia, a razão tornou-se um instrumento. No aspecto formalista da razão subjetiva, sublinhado pelo positivismo, enfatiza-se a sua não referência a um conteúdo objetivo; em seu aspecto instrumental, sublinhado pelo pragmatismo, enfatiza-se a sua submissão a conteúdos heterônomos. A razão tornou-se algo inteiramente aproveitado no processo social. Seu valor operacional, seu papel no domínio dos homens e da natureza tornou-se o único critério para avaliá-la" (HORKHEIMER, 1976, p. 28-29). Em Kant, dir-se-ia que uma razão é instrumental, quando se desenvolve unicamente em seu uso teórico, desconsiderando as exigências de seu uso prático. Tratar-se-ia, nesse caso, de uma razão unicamente heterônoma.
} 
podemos depreender de sua Crítica da Razão prática ${ }^{4}$ (Kritik der praktischen Vernunft, 1788), está subsumido à Razão prática pura (reine praktishe Vernunft).

Todavia, o projeto kantiano está no seio de outra tradição e, mesmo, de outro contexto sociopolítico. Assim, o primeiro ponto a ser distinguido entre os modelos kantiano e habermasiano (paradigmáticos, em seus respectivos contextos históricos) refere-se à mudança de paradigma ${ }^{5}$ proposta por Habermas: enquanto, em Kant, ainda estamos no contexto de um "paradigma da consciência", em Habermas adentramos no "paradigma da linguagem"; ou seja, há a passagem de uma "razão monológica" (relação sujeito-objeto) para uma "razão dialógica" (relação sujeito-sujeito). Nesse sentido, parece-nos lícito afirmar que, em Habermas, falamos mais acertadamente de um "esclarecimento comunicativo"6, dado que muda o sentido dos termos Unmündigkeit e Mündigkeit: o primeiro passa a significar uma incapacidade para fazer um uso apropriado da linguagem ${ }^{7}$, ao passo que o segundo significará a junção dos conceitos chomskianos de competence e performance (regrados, por assim dizer, por critérios normativos de uma ética discursiva - Diskursethik - de jaez deontológico).

O ponto de partida de Habermas é o diagnóstico da modernidade, tal como o encontramos especialmente em T. Adorno e M. Horkheimer ${ }^{8}$. Nestes,

${ }^{4}$ Cf. item III do Cap. II da Dialética da Razão pura prática: "Do primado da razão prática pura na sua conexão com a razão pura especulativa". Diríamos que há, em Kant, uma relação necessária entre "progresso" e moralidade, onde esta última determina, por assim dizer, aquele. Dito de outra forma, o processo rumo à Mündigkeit (a Aufklärung propriamente dita) obedece, em nível teórico e prático, a um mandamento moral, isto é, o processo de Aufklärung é subsumido pelo Sollen.

${ }^{5}$ Poderíamos dizer que os três grandes paradigmas na história do pensamento ocidental são: o ontológico (sobretudo em Platão e Aristóteles), o da consciência (especialmente nos modernos: Descartes e Kant seriam grandes exemplos desse paradigma) e o da linguagem, que surge no contexto contemporâneo e é explorado, sobretudo, por Habermas.

${ }^{6}$ De qualquer forma, mesmo em Kant tal esclarecimento escapa de um solipsismo, ou, ainda, de um mero esclarecimento no tocante à razão teórica (desenvolvimento científico). Em verdade, em Kant a ideia de esclarecimento aponta para um nexo entre história e liberdade.

${ }^{7} \mathrm{Ou}$, ainda, a menoridade, em Habermas, seria uma incapacidade para servir-se da razão comunicativa.

${ }^{8}$ Ver, por exemplo: ADORNO; HORKHEIMER, 1984. Em tal texto, os autores apontam para o insucesso (especialmente a partir do fortalecimento do Positivismo) daquela promessa oriunda do Iluminismo, a saber: a de libertar o homem da ignorância, da "menoridade culpada" da qual nos falava Kant. Nesse sentido, os autores fundam sua crítica à modernidade no reconhecimento de uma "instrumentalização da razão", a qual é expressa historicamente no exemplo de Auschwitz: trata-se, segundo os autores, da razão tornando-se o seu oposto: irracionalidade. E é isso o que ocorre, quando a razão 
há um evidente desencanto no tocante ao poder libertador da razão. Atrelados a Nietzsche, e dando as bases para um "pós-modernismo filosófico", eles expressam reiteradamente suas suspeitas diante do projeto moderno. Tal "crise", aliás, é identificada também (e, talvez, sobretudo) no âmbito da ciência, especialmente a partir do diagnóstico de Edmund Husserl ${ }^{9}$. Aliás, neste encontraremos, embrionariamente, um conceito fundamental para o sistema habermasiano: o conceito de "mundo da vida" (Lebenswelt) ${ }^{10}$. Com efeito, conforme Husserl, as ciências, com sua pretensão de objetividade, afastaramse do "mundo da vida". O pretenso desenvolvimento científico, nos moldes herdados de Galileu, teria causado, ainda segundo Husserl, o empobrecimento do mundo humano, de tal maneira que o objetivismo da ciência teria acarretado dois problemas: em primeiro lugar, o sujeito foi deixado de lado; em segundo lugar, teria havido uma perda da dimensão ética, dos valores.

Além dos autores suprarreferidos, outro diagnóstico assaz valioso para uma compreensão do problema que Habermas tem diante de si é o de Max Weber, o qual contribuiu sobremaneira para o "pessimismo histórico"11 engendrado no seio do século XX. Com efeito, Weber encarava com um evidente pessimismo o crescente racionalismo (ligado a um secularismo) do suposto "progresso" da humanidade. Podemos dizer que, em sua leitura da modernidade, ele conclui que esta se caracterizará especialmente pela institucionalização da racionalidade teleológica (Zweckrationalität), ou seja, pela racionalidade reduzida à seleção dos meios. Há, nesse sentido, o que ele denominou "desencantamento do mundo" (Entzauberung des Welt). Tal

passa a ser instrumento da sociedade vigente. Por esse caminho, chegamos a uma "sociedade totalmente administrada", na qual há uma reificação do próprio homem. Dessa forma, ao obliterar a autonomia, a instrumentalização da razão tornou impensável a própria liberdade. Como dirá Horkheimer: "[...] tendo cedido em sua autonomia, a razão tornouse um instrumento. No aspecto formalista da razão subjetiva, sublinhado pelo Positivismo, enfatiza-se a sua referência a um conteúdo objetivo; em seu aspecto instrumental, sublinhado pelo Pragmatismo, enfatiza-se a sua submissão a conteúdos heterônomos. A razão tornou-se algo inteiramente aproveitado no processo social. Seu valor operacional, seu papel no domínio dos homens e da natureza tornou-se o único critério para avaliá-la" (HORKHEIMER, 1976, p. 28-29, grifo nosso). A propósito, ainda sobre a ausência de uma vida ética na sociedade "totalmente administrada", isso é algo que também pode ser observado em: ADORNO, 1997. Nesta, encontramos diversas Reflexionen aus dem beschädigten Leben.

${ }^{9}$ Sobre esse ponto, veja-se, por exemplo, a importante conferência de Edmund Husserl: Die Krisis der europäischen Wissenschaften und die Transzendentale Phänomenologie. The Hague: M. Nijhoff, 1962.

${ }^{10}$ A respeito dessa questão, ver: OLIVEIRA, 1999.

${ }^{11}$ Expressão utilizada reiteradamente por F. Fukuyama, em seu célebre estudo: FUKUYAMA, F. O fim da história e o último homem. Rio de Janeiro: Rocco, 1992. 
"desencantamento" teria levado a uma burocratização da economia e da administração, bem como a uma formalização do direito, a uma especialização profissional e a uma despersonalização das relações sociais. Na leitura weberiana, a já mencionada institucionalização das atividades com referências a fins se dá nos vários subsistemas sociais (ordens de vida), ocorrendo, primeiro, no "mundo da vida" (Lebenswelt), isto é, na esfera da vida quotidiana, para ulteriormente penetrar na esfera econômica. Nesse sentido, ele inverte a talvez já obliterada teoria marxiana segundo a qual a überbau determina a unterbau (ou, ainda, conforme a qual a ordem econômica determina a esfera quotidiana), dando como exemplo o fato de que a religião protestante determinou a ascensão do capitalismo ${ }^{12}$. Isso se explica em virtude do fato de que a racionalização aconteceu a partir das transformações nas visões religiosas de mundo. Disso adveio o "desencantamento do mundo" (Entzauberung des Welt) e um novo caminho para a salvação, a saber, o trabalho nesse mundo (ao invés da mera contemplação). Esse último ponto será marcado pela atividade metódica e racionalizada em prol do Senhor. Eis o trabalho como vocação. E, assim, uma questão que era apenas de índole religiosa passou a intervir e determinar a economia e a política. Aqui, o trabalho não é mais realizado apenas pelo salário, mas por Beruf. Este será o novo ethos econômico: o trabalho é realizado in majorem Dei gloriam.

Para Habermas, Weber é a única figura clássica na sociologia que rompeu com as premissas de uma filosofia da história, mas que, contudo, quis conceber a modernização da sociedade europeia como resultado de um processo histórico universal de racionalização. De acordo com Habermas, a teoria da racionalização nos permitiria reconstruir o projeto weberiano em sua totalidade ${ }^{13}$.

Na verdade, além de Weber, há outras figuras importantes da Sociologia para a leitura da modernidade feita por Habermas ${ }^{14}$. Autores como

\footnotetext{
12 WEBER, 2004.

13 "Among the classical figure of sociology, Max Weber is the only who broke with both the premises of the philosophy of history and the basic assumptions of evolutionism and who o nonetheless wanted to conceive of the modernization of old european society as the result of a universal-historical process of rationalization" (HABERMAS, 1984, v. 1, p. 143).

${ }^{14}$ No conjunto de uma diversidade de autores citados em seu magistral Theorie des kommunikativen Handelns (1981).
} 
Talcott Parsons ${ }^{15}$, Harold Garfinkel ${ }^{16}$ e Alfred Schüt ${ }^{17}$, entre outros, têm lugar de destaque na discussão proposta por Habermas.

Dado o diagnóstico da modernidade estabelecido por alguns dos autores anteriormente citados, fica a questão: como resgatar o projeto moderno de esclarecimento ${ }^{18}$

Como visto ao início do presente paper, Habermas manterá o projeto moderno, fazendo uma mudança de paradigma. Com base no paradigma de uma razão dialógica, vai levar a efeito um retorno à ideia de Aufklärung. E, com isso, demonstrará que a modernidade é um projeto inacabado ${ }^{19}$. No princípio de sua obra Der Philosophische Diskurs der Moderne ${ }^{20}$ ele faz

\footnotetext{
${ }^{15}$ Segundo este, as motivações dos "atores sociais" são integradas em determinados modelos normativos que regulam os comportamentos. Isso serve, conforme Parsons, para explicar a estabilidade da ordem social e sua consequente reprodução pelos diversos indivíduos. Em suma, compartilhamos valores que estão além de nós. Além disso, para melhor explicar tal "regularidade" no comportamento social, Parsons recorre a Freud: no decorrer de nossa formação, as normas que regram o convívio social são interiorizadas pelos indivíduos (em Freud, isso serviria para constituir o "super ego").

${ }^{16}$ Precursor da etnometodologia, corrente segundo a qual a linguagem ordinária revela, por assim dizer, a realidade social. Tal corrente leva em conta a compreensão que o grupo social tem de si. Assim, há uma preocupação em analisar as crenças e comportamentos do senso comum, enquanto elementos constitutivos de todo comportamento organizado. Além disso, Garfinkel enfatiza a importância do diálogo na pesquisa social. O diálogo seria essencial à coleta de dados: ele caracteriza o processo pelo qual construímos a ordem social. Todavia, segundo a crítica de Habermas (em sua Theorie des kommunikativen Handelns) a Garfinkel, este ainda não distinguiria entre consenso válido e um acordo sem validade (estabelecido coercitivamente).

${ }^{17}$ Em sua The phenomenology of the social world (1932), propõe um estudo dos processos de interpretação utilizados na vida quotidiana, para dar sentido às nossas ações e às ações dos demais. Com efeito, para Schütz, a compreensão está desde sempre realizada no âmago das atividades comuns da vida ordinária. Assim, ele terá uma forte influência na fundamentação do conceito habermasiano de "mundo da vida", especialmente ao levar em conta o mundo social enquanto mundo da vida quotidiana, vivido por pessoas que não partem de um interesse teórico pelo mundo. Tal mundo social seria o mundo intersubjetivo, o mundo da rotina, no qual a maioria dos atos é realizada mecanicamente. ${ }^{18}$ A pragmática universal é precisamente uma resposta a essa questão. Ela seria a ciência reconstrutiva das condições universais de intercompreensão, ou, ainda, a ciência dos pressupostos universais e necessários unicamente sob os quais os sujeitos (compreendidos como capazes de falar e agir) se compreendem mutuamente.

${ }^{19}$ O que ele já expõe em uma conferência de 1980, a qual faz parte da coleção Kleine Politische Schriften (que começa a ser editada em 1981). Ver: HABERMAS, 1995. Muitos temas relevantes são discutidos nesses pequenos escritos, como, por exemplo, a questão da democracia, a concepção de um Welfare State etc.

${ }^{20}$ HABERMAS, 1985.
} 
referência ao título de uma conferência proferida alguns anos antes: "modernidade - um projeto inacabado". Dessa forma, fica clara a pretensão de uma retomada do projeto moderno (ainda que por outro caminho - nesse caso, o de uma reviravolta linguístico-pragmática). Em consequência, cabe trazer a lume um conceito basilar ao sistema de Habermas: o de "ato de fala".

Quando dizer é fazer: descobrimento e desenvolvimento dos "atos de fala"

Habermas desenvolverá a concepção referente aos "atos de fala" ${ }^{21}$ por sua leitura de John Austin, sendo que esta lhe permitirá elaborar um conceito peculiar de "agir social". Na primeira preleção de How to do things with words, ${ }^{22}$ Austin distingue enunciados constatativos de enunciados

${ }^{21}$ A ideia do que seja um "ato de fala", posteriormente cunhada e popularizada por John Searle, foi desenvolvida por John Austin, em doze preleções apresentadas em Harvard, em 1955 (e que constituiriam sua obra póstuma How to do things with words, de1962). A tese central perfilhada em tais preleções é: dizer não se reduz a descrever ou a transmitir informações. Dizer significa atuar sobre o mundo circundante e sobre o interlocutor. Até Austin, os linguistas tratavam das asserções como se estas apenas descrevessem estados de coisas (sendo, pois, ou verdadeiras ou falsas). Por essa razão, ele inicia a primeira preleção, afirmando: "It was for too long the assumption of philosophers that the business of a 'statement' can only be to 'describe' some state of affairs, or to 'state some fact', which it must do either truly or falsely" (AUSTIN, 1975, p. 1). Posteriormente, a teoria dos atos de fala será desenvolvida, no âmbito da filosofia da linguagem (e, posteriormente, de uma filosofia da mente) por John Searle. Em seu fundamental Speech acts (1969), ele logra aprofundar temas já tratados por Austin, Wittgenstein, Strawson e outros. De qualquer maneira, tal estudo será retomado por ele dez anos depois, em seu Expression and Meaning (1979), o qual significará um avanço na teoria dos atos de fala. Nessa última obra, Searle distingue cinco classes de atos de fala: assertivos, diretivos, compromissivos, expressivos e declarativos. Todos terão um "ponto ilocucionário", "uma direção de ajuste" e um "estado psicológico". O ponto ilocucionário diz respeito à força ilocucionária; a direção de ajuste, à relação palavra/mundo; o estado psicológico, por sua vez, concerne à expressão que o falante externa, ao realizar um ato ilocucionário. De qualquer forma, Habermas tecerá diversas críticas à teoria dos atos de fala de Searle. No âmbito dos diretivos, Searle não teria distinguido entre imperativos normativamente autorizados e aqueles que não estão relacionados com normas válidas; quanto aos compromissivos, Searle não teria separado condição de validade de condição de sucesso; quanto aos expressivos, Searle não teria encontrado a direção do ajuste, porque seu modelo não contemplaria a ideia de mundo subjetivo; por fim, quanto aos declarativos, faltaria em Searle a pretensão de retidão normativa

22 AUSTIN, 1975. Além de Austin, também Wittgenstein sustenta que fatores extralinguísticos determinam a construção do significado dos enunciados. Mesmo em seu Tractatus Lógico-Philosophicus (1921), especialmente no aforismo 3.326, encontramos a afirmação: "Um das Symbol am Zeichen zu erkennen, mu? man auf den sinnvollen Gebrauch achten". A importância do uso (Gebrauch) fica explícita, todavia, especialmente 
performativos: os primeiros descrevem estados de coisas e são passíveis do critério de verificabilidade, isto é, ou são verdadeiros ou são falsos; os segundos, por sua vez, não constatam nem descrevem ${ }^{23}$. Em verdade, os performativos executam, realizam ${ }^{24}$. Assim, eles não estão submetidos ao critério de verificabilidade, quer dizer, a eles não cabem os termos verdadeiro/falso. Não obstante ele ser inverificável, o enunciado performativo pode ser ou feliz (happy) ou infeliz (unhappy). Ele é feliz, quando surte efeito e infeliz, quando é sem efeito. Já na Lecture II de seu How to do things with words, Austin estabelece algumas "condições de felicidade": para que um ato de fala seja feliz, deve haver um procedimento convencionalmente aceito, o que inclui a emissão das palavras apropriadas por certas pessoas, em certas circunstâncias; deve haver uma adequação entre as pessoas particulares e as circunstâncias, em um dado caso, e também deve o procedimento ser executado por todos os participantes de modo correto. Em verdade, o insucesso dos enunciados performativos ocorre ${ }^{25}$, principalmente, ou por desacordo (quando o procedimento evocado não é aceito - o que ocorre por diversas razões ) ou por um mau uso da linguagem, caracterizado pela insinceridade por parte do falante. Esse é o ponto explorado por Austin, na Lecture $I V^{26}$ : o insucesso de um enunciado performativo se dá quando aquele que o profere não é sincero em relação ao que está sentindo ${ }^{27}$, pensando ${ }^{28}$ ou pretendendo ${ }^{29}$.

em suas Investigações Filosóficas (Philosophische Untersuchungen, 1953). Dessa maneira, enquanto na primeira (Tractatus...) Wittgenstein estava preocupado com a forma lógica, analisando o mecanismo lógico da linguagem, na segunda (Investigações...), ele vai além da estrutura, ao afirmar: "Não pergunte pelo sentido das palavras, pergunte por suas condições de uso". Nessa mesma obra (cf. prop. 35), ele ainda menciona a existência de "inúmeras espécies diferentes de emprego (Gebrauch) daquilo que chamamos de 'signo', 'palavras', 'frases'". Mais adiante (cf. prop. 340), ele ainda afirma: "Não podemos adivinhar como uma palavra funciona. Temos de ver seu emprego (Gebrauch) e aprender com isso". 23 "They do not 'describe' or 'report' or constate anything at all, are not 'true or false';" (AUSTIN, 1975, p. 5).

${ }^{24} \mathrm{O}$ termo 'performativo' (performative) advém do verbo to perform (realizar, desempenhar, executar...). Na Lecture I, Austin dá alguns exemplos de enunciados performativos: "I name this ship the Queen Elizabeth"; "I bet you sixpence it will rain tomorrow". Um proferimento performativo tem dois níveis: o nível locucionário - semântico - e o nível ilocucionário - pragmático.

${ }^{25}$ Cf. Lecture III.

${ }^{26}$ Cf. p. 40

${ }^{27}$ Quando, por exemplo, em um enunciado performativo como "minhas condolências...", o sujeito não sente coisa alguma.

${ }^{28}$ Quando, por exemplo, em um enunciado performativo tal qual "eu o julgo inocente...", o sujeito creia na culpa daquele que ele declara inocente.

${ }^{29}$ Quando, por exemplo, em um enunciado performativo do tipo "eu prometo...", o sujeito saiba que não irá cumprir a promessa. 
Mais adiante, na Lecture VIII, Austin também estabelecerá algumas distinções fundamentais ao intento de Habermas. Em tal Lecture, Austin especifica o que sejam atos locucionários, atos ilocucionários e atos perlocucionários. Atos locucionários correspondem a enunciados constatativos: têm sentido e referência definidos. Dir-se-ia que eles têm significado. Eles envolvem o simples dizer algo. Eles consistem em proferir sons (consoante uma dada fonética), em articular certas palavras que estejam no âmbito de um vocabulário específico (devendo, também, estar de acordo com a gramática vigente). Os atos ilocucionários são proferimentos com força ${ }^{30}$. Eles correspondem aos enunciados performativos, dado que realizam algo. Os atos perlocucionários, por seu turno, consistem no efeito produzido no interlocutor pelo fato de dizermos algo. Diríamos que os dois primeiros envolvem, sobretudo, convenções linguísticas, ao passo que os terceiros envolvem especialmente consequências. Assim, enquanto os atos ilocucionários pressupõem compreensão, os perlocucionários indicam efeitos (os quais vão além da compreensão) ${ }^{31}$.

Com efeito, tais caracterizações serão fundamentais para o projeto habermasiano. Dessa forma, ele distingue três tipos de efeito perlocucionário e dois tipos de orientação para a ação. Em seu Theorie des kommunikativen Handelns (1981), ele distingue uma orientação para o sucesso (estratégica) de uma orientação para o entendimento (esta relacionada com a ideia de Aufklärung $)^{32}$. Quanto aos efeitos perlocucionários, temos:

1. Aqueles que resultam do significado do ato de fala (compreensão);

2. Aqueles que não resultam do significado do ato de fala, mas que poderiam ser tornados públicos, de tal maneira que isso não afetaria seu resultado final. São, todavia, contingentes, inesperados;

3. Aqueles cujo resultado não teria ocorrido, se o falante tivesse revelado seu propósito. Aqui reside o agir estratégico propriamente dito.

Para exemplificar as distinções acima, poderíamos empregar um exemplo. Imaginemos uma situação dialógica, na qual ocorra a seguinte situação:

Y pergunta a X - Podes me emprestar tal quantia? (enunciado performativo)

$\mathrm{X}$ responde a $\mathrm{Y}$ - Sim, é claro que posso!

${ }^{30}$ Em Habermas, tal "força" será transformada na "pretensão de validade".

${ }^{31}$ Poderíamos distinguir os atos ilocucionários dos atos perlocucionários, utilizando exemplos. "Ao dizer isto (in saying it) eu o estou avisando" (ilocucionário). "Por dizer isto (by saying it) eu o convenci" (perlocucionário).

${ }^{32}$ Ver, por exemplo, no Volume I, a figura 14. Em verdade, trata-se, aqui, da distinção entre agir comunicativo (com vistas à interação social e ao entendimento) e agir estratégico. 
Nesse caso, X compreende e aceita (sucesso ilocucionário) o pedido de empréstimo feito por Y. E, assim, ele empresta a Y o valor solicitado (sucesso perlocucionário). Ao conseguir o empréstimo, Y consegue pagar uma dívida que possuía com Z, o qual consegue resolver seus próprios problemas econômicos (aqui, temos o sucesso perlocucionário do tipo 2: tal fim não estava explicito inicialmente, mas, mesmo que estivesse, isso não afetaria o sucesso da ação comunicativa). Quanto ao efeito perlocucionário 3, este ocorreria, se Y pensasse em usar o dinheiro para, por exemplo, comprar crack: dada a preocupação de X com Y, se ele soubesse do fim que seria dado ao dinheiro, ele jamais o teria emprestado. Por isso, os efeitos perlocucionários do tipo 3 entram no contexto de um "agir estratégico". Tal uso vive "parasitariamente" 33 da utilização da estrutura normal da linguagem. O "agir estratégico" visa à produção de efeitos de modo causal. Ele não visa à compreensão, mas à persuasão do(s) ouvinte(s) ${ }^{34}$.

De qualquer forma, fica claro que Habermas tem em mente a crítica de Adorno e Horkheimer a uma "razão instrumentalizada". A ideia de uma instrumentalen Vernunft, conceito fundado especialmente por Horkheimer,

\footnotetext{
${ }^{33}$ Como salienta Habermas, em um dos ensaios que fazem parte da obra Pensamento pósmetafísico (Nachmetaphysisches Denken: Philosophische Aufsätze): "O uso estratégico latente da linguagem vive parasitariamente do uso normal da linguagem, porque ele somente pode funcionar quando pelo menos uma das partes toma como ponto de partida que a linguagem está sendo utilizada no sentido do entendimento" ("Ações, atos de fala, interações mediadas pela linguagem e mundo da vida". In: HABERMAS, 2002, p. 65-103).

${ }^{34}$ Em sua Kritik der reinen Vernunft (1781) Kant distingue convicção (Überzeugung) de persuasão (Überredung): "Das Fürwahrhalten ist eine Begebenheit in unserem Verstande, die auf objektiven Gründen beruhen mag, aber auch subjektive Ursachen im Gemüte dessen, der da urteilt, erfodert. Wenn es für jedermann gültig ist, so fern er nur Vernunft hat, so ist der Grund desselben objektiv hinreichend, und das Fürwahrhalten heißt alsdenn Überzeugung. Hat es nur in der besonderen Beschaffenheit des Subjekts seinen Grund, so wird es Überredung genannt.Überredung ist ein bloßer Schein, weil der Grund des Urteils, welcher lediglich im Subjekte liegt, für objektiv gehalten wird. Daher hat ein solches Urteil auch nur Privatgültigkeit, und das Fürwahrhalten läßt sich nicht mitteilen. Wahrheit aber beruht auf der Übereinstimmung mit dem Objekte, in Ansehung dessen folglich die Urteile eines jeden Verstandes einstimmig sein müssen (consentientia uni tertio, consentiunt inter se). Der Probierstein des Fürwahrhaltens, ob es Überzeugung oder bloße Überredung sei, ist also, äußerlich, die Möglichkeit, dasselbe mitzuteilen und das Fürwahrhalten für jedes Menschen Vernunft gültig zu befinden; denn alsdenn ist wenigstens eine Vermutung, der Grund der Einstimmung aller Urteile, ungeachtet der Verschiedenheit der Subjekte unter einander, werde auf dem gemeinschaftlichen Grunde, nämlich dem Objekte, beruhen, mit welchem sie daher alle zusammenstimmen und dadurch die Wahrheit des Urteils beweisen warden" (KANT, 2006, B848, p. 829). Tal passagem será sobremaneira importante para compreendermos a ideia de "uso público da razão" em Habermas, uma vez que Kant considera que a convicção é válida para todos aqueles "dotados de razão". A persuasão, por sua vez, vale apenas para o indivíduo conforme sua natureza particular. Ela é, como assevera Kant, ein bloßer Schein.
} 
leva os autores já referidos a um pessimismo quanto ao poder "esclarecedor" da razão ${ }^{35}$. Habermas, por seu turno, estabelece dois modelos de racionalidade, o que lhe servirá tanto para fazer uma crítica à modernidade quanto para prescrever uma alternativa aos problemas engendrados por essa mesma modernidade. De certa forma, poderíamos dizer que Habermas compartilha da crítica à modernidade perpetrada pelos autores citados. Todavia, ele não concorda com as consequências de tal crítica ${ }^{36}$. Em suma, Habermas ainda crê no potencial "esclarecedor", "libertador", da razão. Porém, não mais de uma racionalidade monológica (como nos modernos), mas de uma racionalidade dialógica, sedimentada em uma ética do discurso (Diskursethik).

Eu abordei o agir comunicativo e o estratégico como duas variantes da interação mediada pela linguagem. No entanto, somente o agir comunicativo é aplicável o princípio segundo o qual as limitações estruturais de uma linguagem compartilhada intersubjetivamente levam os atores - no sentido de uma necessidade transcendental tênue - a abandonar o egocentrismo de uma orientação pautada pelo fim racional de seu próprio sucesso e a se submeter aos critérios públicos da racionalidade do entendimento. Podemos, pois, tomar as estruturas supra-subjetivas da linguagem na perspectiva da teoria da ação e tentar encontrar a partir delas uma resposta à questão clássica: como é possível a ordem social ${ }^{37}$

\footnotetext{
${ }^{35}$ Razão pela qual, talvez, Adorno se encaminhe para a estética, isto é, para a ideia de que na arte estaria o potencial crítico, ou, ainda, a possibilidade de "libertação" do sujeito. Nesse sentido, seus estudos nos anos 50 e 60 estarão direcionados especialmente para temas que culminarão na obra (póstuma, de 1970) Ästhetische Theorie (ADORNO, T. Ästhetische Theorie. Gesammelte Werke, v. 7. Frankfurt: Suhrkamp, 1972). Horkheimer, por outro lado, igualmente em sua tentativa de se afastar da ideia de Aufklärung proposta especialmente por Kant (bem como da epistemologia de origem cartesiana), encaminhase para uma religiosidade. Sobretudo em sua obra Eclipse da Razão (originalmente intitulada Eclipse of Reason, mas posteriormente traduzida para o alemão por Zur Kritik der Instrumentellen Vernunft), de 1955, Horkheimer vê na religião a esperança de uma vida mais "autêntica".

${ }^{36}$ Este é um aspecto que também aproxima Habermas dos modernos. Afinal, mesmo colocando a razão (ou o entendimento) no banco dos réus, os modernos o faziam com vistas a dar à razão (ou ao entendimento) uma maior clareza, permitindo-lhe um conhecimento mais seguro. Tal suspeita dos modernos quanto aos poderes da razão (ou do entendimento) era metódica: investigá-la para evitar o dogmatismo e garantir um conhecimento objetivo. No contexto contemporâneo, autores tais quais Adorno e Horkheimer criticam a razão por não mais crerem no seu poder libertador. Por esse motivo, eles encontram refúgio em áreas como a estética (no caso de Adorno) e a religião (no caso de Horkheimer). Ver nota anterior (36).

${ }^{37}$ HABERMAS, 2002, p. 82-83. Tal questão ("como é possível a ordem social?") tem sido respondida, ao longo de todo o pensamento político ocidental, das mais diversas formas. Em linhas gerais, a resposta dada por Habermas a essa questão terá um forte cunho deontológico, no sentido de que ele propõe uma concepção que não está atrelada apenas
} 
A Ética do discurso, em linhas gerais, pode ser compreendida como a relação entre duas ou mais pessoas, mediante conversação argumentativa, em que cada parte está disposta a defender seu ponto de vista, a partir de razões (obedecendo aos princípios normativos do discurso). Subjaz a essa ideia a concepção de um uso público da razão de jaez kantiano ${ }^{38}$. Nessa perspectiva, a Ética do discurso tem por objetivo legitimar certas práticas sociais e políticas. A "pragmática universal" investiga as condições que tornam possível a ação comunicativa ${ }^{39}$. Sua preocupação é: como é possível um uso da linguagem orientado para o esclarecimento?

a meros arranjos sociais (em um "cálculo de interesses", no sentido hobbesiano). Afinal como diz Kant em seu opúsculo Zum ewigen Frieden (1795), "o problema do estabelecimento do Estado, tão duro como isso soe, pode ser solucionado mesmo para um povo de demônios (se somente eles tiverem entendimento) e exprime-se assim: 'ordenar uma multidão de seres racionais, que no todo exigem leis universais para sua conservação, das quais, porém, cada um está inclinado a fazer-se exceção em segredo, e estabelecer sua constituição de modo que, embora eles tentem uns contra os outros em suas disposições privadas, as contenham uns aos outros de modo que o resultado de sua conduta pública seja justamente o mesmo como se não tivessem nenhuma das tais más disposições" (KANT, 1989, 366, p. 53). Dessa forma, como bem esclarecem autores como D. Hume, T. Hobbes, D. Gauthier e outros, não são necessários fundamentos éticos para garantir a estabilidade (ordem) social. O simples interesse particular poderia servir como motivo para a criação de uma ordem social. Todavia, modelos tais quais os de Kant e de Habermas dão uma ênfase no déon, ou seja, a primazia está em uma concepção formal, em critérios normativos e em um ideal também normativo de pessoa (sujeito capaz de agir racionalmente, de alcançar um "uso público" de sua razão). No caso de Habermas, a primazia está na Diskursethik.

${ }^{38}$ Expressa no já citado Beantwortung der Frage: Was ist Aufklärung?

39 " [...] chamo comunicativas às interações nas quais as pessoas envolvidas se põem de acordo para coordenar seus planos de ação, o acordo alcançado em cada caso medindose pelo reconhecimento intersubjetivo de pretensões de validez... [que] os atores erguem com seus atos de fala [...] No agir comunicativo um é motivado racionalmente pelo outro para uma ação de adesão — e isso em virtude do efeito ilocucionário de comprometimento que a oferta de um ato de fala suscita. Que um falante possa motivar racionalmente um ouvinte à aceitação de semelhante oferta [se explica] pela garantia assumida pelo falante, tendo um efeito de coordenação, de que se esforçará, se necessário, para resgatar a pretensão erguida... Tão logo o ouvinte confie na garantia oferecida pelo falante, entram em vigor aquelas obrigações relevantes para a seqüência da interação que estão contidas no significado do que foi dito... Graças à base de validez da comunicação voltada para o entendimento mútuo, um falante pode, por conseguinte, ao assumir a garantia de resgatar uma pretensão de validade criticável, mover um ouvinte à aceitação de sua oferta de ato de fala e assim alcançar para o prosseguimento da interação um efeito de acoplagem assegurando a adesão" (HABERMAS, 2003, p. 79). 


\section{Elementos normativos para uma ética do discurso}

$\mathrm{E}$, com isso, chegamos aos elementos normativos de uma ética do discurso: o princípio de universalização ${ }^{40}$, o princípio do discurso e as pretensões de validade. O princípio de universalização seria uma reformulação discursiva do imperativo categórico kantiano ${ }^{41}$. Na formulação que dá o próprio Habermas: "[...] uma norma de ação só é válida se todos os que podem se ver afetados por ela (e pelos efeitos de sua aplicação) chegarem, como participantes de um discurso prático, a um acordo (racionalmente motivado) acerca de se a norma há de entrar (ou seguir) em vigor". Ou seja, tal princípio garante a racionalidade do discurso, sendo que age moralmente quem age de acordo com uma norma de ação que possa ser universalizada, isto é, que possa obter o consenso de uma comunidade ideal de comunicação. Em outras palavras, age moralmente quem age consoante uma norma de ação que possa ser universalizada, ou, ainda, que possa obter o consenso de uma comunidade ideal de comunicação. O princípio do discurso, por seu turno, implica que não podemos reivindicar algo como válido a não ser aquilo que possa ser fundamentado racionalmente por meio de argumentos. E, por fim, as pretensões de validade: 1 .verdade $(\text { Wahrheit })^{42} ; 2$. retitude

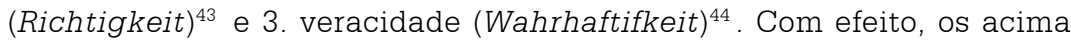
aventados elementos normativos garantem que a ação comunicativa seja bem sucedida, quer dizer, que haja consenso. Dito de outra forma, eles garantem a inteligibilidade do ato de fala. Como background de sua teoria está um conceito que é fundamental à Diskuretik: o de contradição performativa, engendrado originariamente por Karl Otto Apel. Assim como adapta à ética do discurso um dos mais sólidos princípios da filosofia prática (der kategorische Imperativ), Habermas também se apropria - via Apel - de um dos mais incontestáveis princípios teóricos do pensamento ocidental, o princípio de não contradição aristotélico. Assim, a contradição performativa tem como base o argumento utilizado por Aristóteles, em sua Metaphysica, contra o cético. Aliás, a despeito da distância histórica, Apel também está enfrentando o cético. Sem dúvida, o pensamento de autores como Karl Popper

\footnotetext{
${ }^{40} \mathrm{O}$ princípio de universalização (U) é o "princípio-ponte que torna possível o acordo em argumentações morais" (HABERMAS, 2003, p. 78)

41 "Handle nur nach derjenigen Maxime, durch die du zugleich wollen kannst, daß sie ein allgemeines Gesetz werde" (KANT, I. Grundlegung zur Metaphysik der Sitten. 1785, BA 421).

${ }^{42} \mathrm{O}$ enunciado deve ser verdadeiro (corresponder à realidade);

${ }^{43} \mathrm{O}$ enunciado deve estar de acordo com as normas vigentes;

${ }^{44}$ A intenção expressa externamente deve estar de acordo com a intenção íntima do falante.
} 
e Hans Albert exigiram dos programas fundacionalistas uma resposta. Em filosofia prática, tal resposta é oferecida por Apel. O "racionalismo crítico" de K. Popper encontra vigor especialmente com a crítica aos modelos fundacionais feita por Hans Albert, com seu célebre "trilema de Münchhausen". Em seu Traktat über kritische Vernunft ${ }^{45}$, de 1968, H. Albert pretende demonstrar que toda tentativa de fundamentar uma determinada teoria conduz ao seguinte trilema: 1 . caímos em um regresso ao infinito; 2. recorremos a um ato arbitrário de parada; 3. caímos em uma circularidade viciosa. Estas seriam, segundo $H$. Albert, as três únicas alternativas àqueles que pretendessem um modelo válido apoditicamente ${ }^{46}$.

Não obstante, contra H. Albert, e encontrando força em Aristóteles, Apel visará a uma fundamentação. Desse modo, tendo Aristóteles como base $^{47}$, Apel logra demonstrar que há princípios inevitáveis, de tal forma que aqueles que os negam recaem, invariavelmente, em uma contradição (a

\footnotetext{
${ }^{45}$ ALBERT, Hans. Traktat über kritische Vernunft. Stuttgart: UTB, 1991. Em tal obra, a tese do "falibilismo" encontra sustentação argumentativa. Todavia - e isso é algo que Apel tenta esclarecer -, tal tese se torna contraditória, se aplicada a si mesma. Por isso, voltamos ao milenar "paradoxo do mentiroso". Ora, aquele que afirma "todos os homens são mentirosos" cai em contradição performativa. Aliás, uma interessante discussão em torno de tal paradoxo nós a encontramos em Alfred Tarski (The Semantic Conception of Truth and the Foundations of Semantics, de 1944) e na crítica a este feita por Saul Kripke (Outline of a Theory of Truth, de 1975). A partir da discussão exposta em tais obras, percebe-se que a questão em torno de tal paradoxo está longe de encontrar uma resposta definitiva.

${ }^{46}$ E tais tentativas já se mostram nos primórdios do pensamento ocidental, especialmente com Platão (veja-se seu Teeteto) e com Aristóteles (e seu recurso ao nous).

${ }^{47}$ Tal força, Apel a encontra especialmente no livro ? da Metaphysica, no qual Aristóteles refuta o cético: "There are some who, as we said, both themselves assert that it is possible for the same thing to be and not to be, and say that people can judge this to be the case. And among others many writers about nature use this language. But we have now posited that it is impossible for anything at the same time to be and not to be, and by this means have shown that this is the most indisputable of all principles.-Some indeed demand that even this shall be demonstrated, but this they do through want of education, for not to know of what things one should demand demonstration, and of what one should not, argues want of education. For it is impossible that there should be demonstration of absolutely everything (there would be an infinite regress, so that there would still be no demonstration); but if there are things of which one should not demand demonstration, these persons could not say what principle they maintain to be more self-evident than the present one. We can, however, demonstrate negatively even that this view is impossible, if our opponent will only say something; and if he says nothing, it is absurd to seek to give an account of our views to one who cannot give an account of anything, in so far as he cannot do so. For such a man, as such, is from the start no better than a mere plant. Now negative demonstration I distinguish from demonstration proper, because in a demonstration one might be thought to be begging the question, but if another person is
} 
contradição performativa propriamente dita). Portanto, aquele que pretende problematizar a questão da justificação dos princípios da moral toma, efetivamente, parte na discussão. Logo, mesmo para argumentar contra a justificação, é necessário tomar parte da discussão, ou, ainda, recorrer aos pressupostos da argumentação. Com base no acima exposto, Karl Otto Apel engendrará ${ }^{48}$ sua concepção de "contradição performativa", a qual ocorre quando o conteúdo daquilo que é asserido contradiz o ato mesmo de asserir. Eis um exemplo de contradição performativa: "Eu, aqui e agora, não existo". Ora, o próprio ato de asserir contradiz o conteúdo asserido. Isso significa que asserir algo implica, necessariamente, levantar pretensões de validade. Assim, conforme Apel, quem argumenta ${ }^{49}$ seriamente aceita o "ponto de vista da razão", reconhecendo a validade das regras do discurso. Quem se recusa a acatar tais regras deve simplesmente não $\operatorname{argumentar}^{50}$. Em Apel, o cético não deve entrar na discussão, não deve participar da interação discursiva. Como salienta Apel:

Aquilo que não posso contestar sem cometer uma auto-contradição atual e, ao mesmo tempo, não posso fundamentar dedutivamente sem uma petitio principii lógico-formal pertence àquelas pressuposições pragmático-transcendentais da argumentação, que é preciso ter reconhecido desde sempre, caso o jogo de linguagem da argumentação deva conservar o seu sentido ${ }^{51}$.

responsible for the assumption we shall have negative proof, not demonstration. The starting-point for all such arguments is not the demand that our opponent shall say that something either is or is not (for this one might perhaps take to be a begging of the question), but that he shall say something which is significant both for himself and for another; for this is necessary, if he really is to say anything. For, if he means nothing, such a man will not be capable of reasoning, either with himself or with another. But if any one grants this, demonstration will be possible; for we shall already have something definite. The person responsible for the proof, however, is not he who demonstrates but he who listens; for while disowning reason he listens to reason. And again he who admits this has admitted that something is true apart from demonstration (so that not everything will be 'so and not so' " (BARNES, 1995, v. 2, p. 1588). Com efeito, por meio dessa "demonstração elêntica", Aristóteles está refutando aquele que nega o princípio de "nãocontradição". Tal princípio, indemonstrável, não pode ser negado por aquele que diz algo. Daí aquele que o nega, se reduzir a uma mera "planta".

48 APEL, 2000

${ }^{49}$ E notemos que Apel, tal como Habermas, está pressupondo a intersubjetividade.

${ }^{50}$ Lembremos que, quanto a este sujeito - o cético propriamente dito - Aristóteles será enfático: Aquele que não aceita o princípio de "não-contradição" deve comportar-se como uma planta.

${ }^{51}$ APEL apud HABERMAS, 2003. 
Em suma, diante da ideia de contradição performativa, só restam duas alternativas: 1 . Ou o sujeito percebe e aceita o fato de que está desde o início utilizando certos princípios indemonstráveis, para fundamentar sua posição, ou 2. Sai da discussão. Em resumo, Apel percebe que toda a discussão argumentativa (teórica ou prática) pressupõe certas regras das quais não há como evadir-se. Renunciá-las significaria renunciar ao discurso (à participação no discurso). Esse será um dos alicerces da ética do discurso ${ }^{52}$, o qual garantirá a própria ideia de fundamentação.

Por conseguinte, as já mencionadas "pretensões de validade" (subsumidas sob o conceito mais abrangente de inteligibilidade) possuem "evidência performativa"53.

Agora, no tocante aos pressupostos, Habermas apoia-se no "catálogo" de pressupostos argumentativos apresentado por Robert Alexy ${ }^{54}$ : 1. "a nenhum falante é lícito contradizer-se"; 2. "todo falante que aplicar um predicado $\mathrm{F}$ a um objeto a tem que estar disposto a aplicar $\mathrm{F}$ a qualquer outro objeto que se assemelhe a a, sob todos os aspectos relevantes"; e 3 . "não é lícito aos diferentes falantes usar a mesma expressão em sentidos diferentes" 55 . Além dos pressupostos acima, Habermas adota ainda as seguintes regras: 1. "a todo falante só é lícito afirmar aquilo em que ele próprio acredita" e 2. "quem atacar um enunciado ou norma que não for objeto da discussão tem que indicar uma razão para isso" ${ }^{56}$.

A partir do catálogo de Alexy/Habermas, vemos que o falante sempre evoca pretensões de validade. E, ao fazê-lo, aceita, "intuitivamente", as condições do discurso. Como assevera Habermas:

Se todos os que entram em argumentações têm que fazer, entre outras coisas, pressuposições cujo conteúdo pode ser apresentado sob forma das regras do discurso; e se, além disso compreendemos as normas justificadas como regrando matérias sociais no interesse comum de todas as pessoas possivelmente concernidas, então todos os que compreendem seriamente a tentativa de resgatar discursivamente pretensões de validez normativas aceitam intuitivamente condições de procedimento que equivalem a um reconhecimento implícito de

\footnotetext{
52 Esta contém o a priori racional que garante a fundamentação dos princípios da ética.

${ }^{53}$ Não podemos, por exemplo, asserir: "Não pretendo que o que estou dizendo seja verdade". Tal asserção reivindica e suprime, simultaneamente, a pretensão de verdade.

${ }^{54}$ Em sua tese defendida em 1976, posteriormente (1983) publicada como Theorie der juristischen Argumentation. Die Theorie des rationalen Diskurses als Theorie der juristischen Begründung, Alexy (inspirando-se em Habermas) estabelece de forma, digamos, didática, tais pressupostos.

${ }^{55}$ HABERMAS, 2003, p. 110.

${ }^{56}$ HABERMAS, 2003, p. 111.
} 


\begin{abstract}
"U". Pois, das mencionadas regras do discurso resulta que uma norma controversa só pode encontrar assentimento entre os participantes de um discurso prático, se "U" é aceito, isto é: se as conseqüências e efeitos colaterais, que previsivelmente resultam de uma obediência geral da regra controversa para a satisfação dos interesses de cada indivíduo, podem ser aceitos sem coação por todos. ${ }^{57}$
\end{abstract}

Tal "situação ideal de fala"58 (Ideale Sprechsituation) nos apresenta as condições mediante as quais avaliamos as situações reais. Ela é uma suposição contrafática que nos permite ter elementos normativos na avaliação dos acordos obtidos faticamente ${ }^{59}$.

Com efeito, Habermas transforma, por conseguinte, uma teoria dos atos de fala (Sprechakte) em uma pragmática universal (Universalpragmatik). Com isso, chegamos à própria taxonomia habermasiana dos atos de fala, a qual ele estabelece levando em conta sua ontologia dos três mundos. Tal ontologia dos três mundos envolve: 1. mundo subjetivo (interno), o qual é constituído pelos sentimentos, crenças, desejos, intenções etc.; pelo 2. mundo social (mundo comum), o qual é constituído pelas normas, instituições aos quais os atores sociais pertencem etc.; e 3. pelo mundo objetivo (externo), que é o mundo dos objetos e dos estados de coisas. Dito de outra forma: quando realizamos um proferimento, nos relacionamos com o mundo objetivo

${ }^{57}$ HABERMAS, 2003, p. 115-116. Ou, como ele dirá mais adiante (p. 161), nessa mesma obra: "[...] a ética do discurso vale-se de argumentos transcendentais que demonstram a impossibilidade de se rejeitarem determinadas condições. Com sua ajuda, pode-se demonstrar a um oponente que ele recorre performativamente a algo que deveria ser suprimido e comete assim uma contradição performativa. Na fundamentação de ' $U$ ', tratase especialmente da identificação de pressupostos pragmáticos sem os quais o jogo da argumentação não funciona. Qualquer um que participe de uma prática argumentativa já deve ter aceito essas condições de caráter normativo. Pelo simples fato de terem passado a argumentar, os participantes estão necessitados a reconhecer esse fato. A comprovação pragmático-transcendental serve, pois, para nos conscientizarmos do conjunto de condições sob as quais já nos encontramos desde sempre em nossa prática argumentativa, sem a possibilidade de nos esquivar em alternativas; a falta de alternativa significa que essas condições são, de fato incontornáveis para nós".

58 "Habermas esclarece-nos, ressaltando que não podemos considerar a situação de fala ideal um fenômeno empírico, um consenso fático. Tampouco é um simples constructo racional. Ela constitui uma suposição ou antecipação contra fática que fazemos necessariamente sempre que entramos num processo discursivo argumentativo [...]. Nesse sentido, a situação de fala ideal constitui uma medida da crítica porque serve para questionar qualquer consenso obtido faticamente, submetendo-se à ideia de um consenso ideal, que jamais será atingido concretamente" (SIEBENEICHLER, 2003).

59 Percebe-se, pois, que a ética habermasiana é formal (Formalistisch), universal (Universalistisch), cognitivista (Kognitivistisch) e deontológica (Deontologisch). 
das coisas (evocando pretensão de verdade), com os demais sujeitos - com o mundo social - (evocando pretensão de retitude) e com nosso mundo subjetivo - com nossos sentimentos, desejos, intenções - (evocando pretensão de veracidade).

Tal distinção pode ser mais bem visualizada no seguinte quadro sinótico:

\begin{tabular}{|c|c|c|c|}
\hline Ato de fala & Pretensão & Mundo & Função pragmática \\
\hline 1. Constatativo & Verdade $^{60}$ & Objetivo & Representativa \\
\hline 2. Expressivo & Veracidade ${ }^{61}$ & Subjetivo & Expressiva \\
\hline 3. Regulativo & Retitude $^{62}$ & Social & Regulativa \\
\hline 4. Imperativo ${ }^{63}$ & Força/poder & Objetivo & Imperativa \\
\hline
\end{tabular}

Tendo o texto publicado em 1934 por Karl Bühler ${ }^{64}$ como base, Habermas fixa sua própria taxonomia dos atos de fala. Em primeiro lugar, temos os atos de fala constatativos, os quais se limitam a apresentar estados de coisas. Dizem respeito à verdade e ao mundo objetivo, sendo sua função meramente representativa ${ }^{65}$. Os atos de fala expressivos apresentam algo referente ao mundo subjetivo do falante. Referem-se, pois, à veracidade (sinceridade) e à função expressiva ${ }^{66}$. Estes "funcionam" quando o ouvinte reconhece a sinceridade do falante. Os regulativos, por seu turno, garantem a interação entre os atores sociais e o mundo social, respectivamente. Há, aqui, uma pretensão de retidão. Tal ato de fala funciona (é feliz), quando

\footnotetext{
${ }^{60}$ Evocamos pretensões de verdade com relação ao mundo objetivo acerca do qual estamos falando.

${ }^{61}$ Evocamos pretensões de veracidade com relação aos nossos sentimentos - mundo subjetivo - expressos no proferimento.

${ }^{62}$ Evocamos pretensões de retitude com relação aos valores e normas compartilhados em nosso mundo social.

${ }^{63}$ Tal ato de fala é ilegítimo, dado que ele não visa ao entendimento, mas ao domínio. Aqui estaria o uso parasitário da linguagem. Afinal, aqui o entendimento não ocorre, dado que o ouvinte não pode tomar uma posição: o entendimento ocorre se, e apenas se, ele sabe o que torna aceitável tal proferimento.

${ }^{64}$ BÜHLER, K. Sprachtheorie. Die Darstellungsfunktion der Sprache. Stuttgart: Gustav Fischer, 1982. Com efeito, as funções pragmáticas apontadas por Habermas são uma apropriação das definições dadas por Bühler.

${ }^{65}$ Por exemplo, quando digo: "A porta está fechada".

${ }^{66}$ Por exemplo, quando digo: "Eu gostaria que a porta estivesse fechada".
} 
aplicado no contexto apropriado ${ }^{67}$. E há, também, os atos de fala imperativos. Estes são usados pelo falante para produzir (teleologicamente, portanto) um desejado estado de coisas, com a expectativa de que o ouvinte realize (ou contribua para) tal estado. Concernem ao mundo objetivo, sendo que sua pretensão é a força ${ }^{68}$. Assim, o entendimento somente acontece nos três primeiros tipos de atos de fala e pressupõem, não obstante, os elementos normativos anteriormente expostos. Habermas enfatiza:

O ouvinte precisa ter razões para aceitar (ou questionar) uma asserção como verdadeira, uma ordem como legítima, uma promessa como obrigatória, uma confissão como autêntica ou sincera. Sem o conhecimento das condições para a tomada de posição em termos de sim/não, o ouvinte não conseguirá entender a ação de fala. ${ }^{69}$

Isso implica, como mencionado alhures, uma ideia de uso público ${ }^{70}$ da razão, isto é, de uma racionalidade compartilhada ${ }^{71}$. Quando Habermas

${ }^{67}$ Por exemplo, quando digo: "Eu te peço que, por favor, feche a porta". Nessa situação, estão envolvidas, por exemplo, regras socialmente estimadas de polidez.

${ }^{68}$ Por exemplo, quando digo: "Feche a porta!!!" Aqui a função é "apelativa" (cf. Bühler). Em geral, tais atos de fala envolvem sanções, de tal forma que o ouvinte é motivado pelo temor a estas (e não por compreensão e entendimento - por esclarecimento).

${ }^{69}$ HABERMAS, 2002, p. 146. Dessa forma, Habermas vai além de uma mera teoria dos atos de fala. Ele introduz elementos tais como "motivação racional"; "efeito ilocucionário de comprometimento"; "assentimento racionalmente motivado" etc.

${ }^{70}$ Publicum deriva do latim publicus, o qual está ligado, por sua vez, ao conceito de populus, isto é, de uma "comunidade de seres humanos" (Ver: PEREIRA, 2002).

${ }^{71}$ Em outro opúsculo, Kant trata de forma clara tal ideia. No Was heisst: sich im Denken orienteren (1786), Kant sustenta que pensamos por nós mesmos, quando verificamos se as razões que temos para aceitar um argumento podem ser transformadas em princípios universais ou, ainda, se, ao aceitarmos um argumento, devemos também pretender que ele seja aceito por todos os demais sujeitos racionais. Isso envolve, portanto, interlocução, inclusão. Na verdade, Kant está propondo que devemos agir conforme princípios os quais podem ser concebidos como válidos também para os demais "sujeitos racionais". Todavia, deve-se observar que Kant, embora tenha uma concepção normativa de sujeito, alude especialmente a um sujeito racional enquanto "erudito"(Gelehrter): "Dagegen als Gelehrter, der durch Schriften zum eigentlichen Publikum, nämlich der Welt, spricht, mithin der Geistliche im öffentlichen Gebrauche seiner Vernunft, genießt einer uneingeschränkten Freiheit, sich seiner eigenen Vernunft zu bedienen und in seiner eigenen Person zu sprechen". Assim, Kant tem em mente um "erudito" falando com um "público letrado" (Leserwelt): "Ich verstehe aber unter dem öffentlichen Gebrauche seiner eigenen Vernunft denjenigen, den jemand als Gelehrter von ihr vor dem ganzen Publikum der L e s e r w e l t macht" (KANT, I. Beantwortung der Frage: Was ist Aufklärung. In: Bahr, Ehrhard (Org.). Was ist Aufklärung? Stuttgart: Reclam, 2004). Habermas se aproxima dessa posição, se considerarmos que ele se apropria dos já referidos conceitos de competence (conhecimento da língua) e performance (uso efetivo da linguagem em situações concretas), engendrados por Chomsky. 
destaca que o ouvinte deve "entender" o ato de fala, ele está evocando precisamente a ideia de Aufklärung, aqui identificada com a concepção de entendimento (Verständigung), ou seja, de um acordo obtido racionalmente ${ }^{72}$. Diferentemente do conceito kantiano de entendimento (Verstand), o entendimento em Habermas está sempre em movimento. Ele pressupõe diálogo, interação social mediante a linguagem. Todo consenso pode ser alterado, revisto, superado. São perenes apenas os elementos normativos (pressupostos, regras e princípios, respectivamente), os quais caracterizam o elemento procedimental de uma ética do discurso. Com efeito, em uma discussão orientada para o entendimento partimos de um "horizonte": o mundo da vida (Lebenswelt). Tal mundo envolve as estruturas de um conhecimento pré-teórico. Ele é uma "realidade pré-estruturada simbolicamente", um "conjunto de sentidos gramaticalmente prédeterminados". Ele está implícito nas asserções ${ }^{73}$. O Lebenswelt é, em uma terminologia hegeliana, o mundo da eticidade (Sittlichkeit), ao passo que a ética do discurso (a racionalidade comunicativa) corresponderia à moralidade $(\text { Moralität })^{74}$. Isso se dá porque o entendimento só pode ocorrer em um "mundo familiar", um mundo compartilhado. Desse modo, Habermas indica que o sujeito traz para a discussão uma série de elementos não tematizados, não problematizados. O Lebenswelt tem como elementos estruturais a

\footnotetext{
${ }^{72}$ Reitere-se que a única forma legítima de consenso refere-se ao "dar razões". Apenas nesse caso há um reconhecimento intersubjetivo. Outras formas de garantir o consenso (tais como apelo à tradição, à força ou à autoridade) consistem naquilo que Noam Chomsky acertadamente nomeia de Manufacturating Consent (cf. CHOMSKY; HERMAN, 1988). Sobre tal uso, afirma Habermas: "[...] existe, no entanto, o caso do agir de fala latentemente estratégico, que visa efeitos perlocucionários não regulados convencionalmente. Esses efeitos só podem surgir quando o falante não declara ao ouvinte seus fins no âmbito da definição comum da situação. Assim procede, por exemplo, um orador na ânsia de persuadir seu público, talvez porque lhe faltem na situação dada argumentos convincentes. Esses efeitos perlocucionários não-públicos só podem ser obtidos de modo parasitário, a saber, sob a condição de que o falante simule a intenção de perseguir sem reservas seus fins ilocucionários, quando na realidade está ferindo os pressupostos do agir orientado para o entendimento e ocultando esse fato do ouvinte. O uso latentemente estratégico da linguagem é parasitário, porque ele só funciona quando, pelo menos uma das partes, parte do pressuposto que a linguagem está sendo utilizada com o fim do entendimento. Quem age estrategicamente, precisa ferir de modo imperceptível as condições de sinceridade do agir comunicativo" (HABERMAS, 2002, p. 132).

${ }^{73}$ Em Habermas está presente a ideia, já sustentada pelo Wittgenstein das Investigações, segundo a qual as palavras adquirem significado no, digamos, devir da vida mesma.

${ }^{74}$ Lebenswelt (a eticidade habermasiana) é a esfera na qual encontramos o conteúdo das normas, ao passo que a racionalidade comunicativa justifica tal conteúdo. Diríamos, parafraseando a célebre frase de Kant: a eticidade sem a moralidade é cega; a moralidade sem a eticidade é vazia.
} 
cultura $^{75}$ (ou, ainda, o patrimônio cultural da comunidade na qual o indivíduo está inserido, em que este encontra os elementos semânticos da tradição que são utilizados na discussão), a sociedade ${ }^{76}$ (a qual é composta pelos ordenamentos que regram a relação de solidariedade entre os indivíduos de determinado grupo) e a personalidade ${ }^{77}$ (formada por um conjunto de competências que habilitam o indivíduo para que este participe das interações que lhe facultam consolidar sua identidade pessoal). A cada elemento corresponde um processo de reprodução: reprodução cultural (cultura), integração social (sociedade) e socialização (sociedade). A crise é oriunda precisamente da "colonização" desse mundo pela esfera sistêmica ${ }^{78}$. Ora, o sistema (System) caracteriza-se exatamente por ter como regras as determinações do mercado e do Estado.

Como salienta Siebeneichler, em seu estudo seminal sobre Habermas:

Habermas descobre o alastramento irracional de formas de racionalidade econômica e administrativa, destituídas de linguagem, as quais passam a infiltrar-se subrepticiamente em esferas vitais que são estruturadas sempre de acordo com um sentido ético, estético e comunicativo, fragmentando-as. Este alastramento conduz à "colonização do mundo da vida", ou seja, à demolição e ao saque de elementos não regeneráveis da tradição cultural ${ }^{79}$.

Com efeito, o Lebenswelt corresponderia às relações sociais quotidianas, ao passo que o "sistema" envolveria certos sistemas sociais, tais

\footnotetext{
${ }^{75}$ Ao se entenderem mutuamente, os participantes da interação se movem dentro de certa tradição cultural.

${ }^{76}$ Ao coordenarem sua ações (por meio de um reconhecimento intersubjetivo de pretensões de validade suscetíveis de crítica), os participantes da interação social apoiam-se em elementos do grupo (social) a que pertencem.

77 Ao se relacionarem com seus "referenciais", as crianças internalizam as orientações valorativas de seu grupo, adquirindo "capacidades de ação".

${ }^{78}$ Tal invasão sistêmica seria a causa da "crise" percebida na modernidade, revelada por uma série de manifestações: Greenpeace, ONGs, protestos, a própria desobediência civil etc. O capitalismo moderno seria, com efeito, o grande responsável por essa invasão. Em verdade, o Lebenswelt necessita de dois elementos: uma infraestrutura comunicativa, a qual é afetada pelo uso instrumental da linguagem, e uma tradição cultural, por sua vez, afetada pelo empobrecimento cultural.

${ }^{79}$ SIEBENEICHLER, 2003, p. 39. Outra obra precursora das reflexões sobre o pensamento de Habermas no Brasil é o livro do Professor Delamar Volpato Dutra: DUTRA, 1993. Além disso, o Professor Delamar tem, desde a publicação da obra citada, contribuído intensamente (com livros e artigos) para uma ampliação das discussões sobre Habermas no Brasil, sendo, dessa forma, uma referência para tais discussões.
} 
como a política, a economia etc. Enquanto o "mundo da vida" pressupõe solidariedade, o "sistema" envolve uma mera integração funcional. O, digamos, "êxito" da racionalidade social estratégica depende do sistema social envolvido. Por exemplo, no plano econômico, o êxito é evidenciado pelo dinheiro obtido. Na política, o êxito é revelado pelo poder alcançado. Há sempre, no âmbito do agir estratégico, um telos ilegítimo (em geral riqueza e poder) ${ }^{80}$.

De qualquer maneira, a ética do discurso representa uma normatividade moral, sendo procedimental em virtude de oferecer procedimentos que, se observados, garantem a legitimidade dos acordos racionais obtidos discursivamente. Em acréscimo, tal normatividade garante mesmo a legitimidade das instituições sociais que regulam a vida dos indivíduos. Nesse sentido, alguns outros pressupostos são essenciais à legitimidade do consenso: 1. "todo sujeito com competência para falar e agir pode tomar parte no discurso"; 2. "todos podem, baseados em razões, questionar qualquer asserção"; 3. "todos têm o direito de asserir, a partir de razões"; 4. "todos têm o direito de expressar desejos, anelos etc."; 5. "falante algum poderá ser, mediante coerção, impedido de exercer os direitos acima". Novamente, estamos pressupondo uma espécie de volonté générale, no sentido rousseauniano. Como é sabido, Rousseau, após a severa crítica ao bourgeois, em seus dois primeiros "discursos" 81 , tenta, com o "Contrato Social", reintegrar o homem à sua natureza "boa"82 (le Bon sauvage). A volonté générale é, em Rousseau, a única fonte de legitimidade da lei ${ }^{83}$. Ela

\footnotetext{
${ }^{80}$ Ainda na Teoria do agir comunicativo (em 1981, pois), Habermas crê que mesmo o Direito faz parte da esfera sistêmica, sendo uma forma de "dominação legal". Nos anos 90, entretanto, Habermas reconsidera tal posição e a apresenta em seu fundamental Faktizität und Geltung: Beiträge zur Diskurstheorie des Rechts und des demokratischen Rechtsstaates (Frankfurt a.M: Suhrkamp Verlag, 1992), no qual o Direito adquire um novo estatuto: aqui ele é capaz de absorver as reivindicações do Lebenswelt (estas obtidas comunicativamente).

${ }^{81}$ Discours sur les sciens sur l'origine et les fondements de l'inégalité parmi les hommes, de 1755. Ambos os discursos sustentam que o assim chamado ,progresso civilizatóriop corrompeu o homem, colocando-o em um mundo de aparências e falsas necessidades. No segundo discours (1755), Rousseau utiliza do conceito de estado de naturezae, pela primeira vez, para indicar o ,grau zerog (a-histórico, portanto) da história humana. Entretanto, em momento algum Rousseau propõe um retorno ao estado de naturezae. Ele acredita na recuperação individual ? das condições originárias de inocência e pureza ? (leia-se Émile, 1762) e coletiva ? via Estado e instituições ? (leia-se Du Contract social, 1762). Aliás, um , pactop nos moldes propostos em O contrato social garante a dignidade e autonomia humanas. Eis a importância do conceito de vontade geralv.

${ }^{82}$ Aquele que segue a "voix de la nature": "l'homme naturel". Como sustenta Rousseau: "La nature a fait l'homme heureux et bon, mais la société le déprave et le rend misérable". De qualquer forma, Rousseau utiliza dessa expressão para criticar a sociedade de então (não se trata, como em Montaigne em seus Essais, de um elogio aos selvagens).

${ }^{83}$ Ela é inalienável, infalível, indivisível e absoluta.
} 
representa o interesse comum, garantindo a justificação ética das instituições (sobretudo do Estado) ${ }^{84}$. Nesse ínterim, Rousseau apresenta um conceito caro (em sua acepção rousseauniana) à filosofia prática vindoura: o conceito de liberdade. Com efeito, segundo Rousseau (no Contrato social), a liberdade é a "obediência à lei que se prescreve a si mesmo"85. Isso implica, necessariamente, a ideia normativa de uma "vontade geral": em virtude desta, súdito e soberano se identificam.

De qualquer maneira, a volonté générale é o que há em comum entre todas as vontades individuais, garantindo que as deliberações sejam justas ${ }^{86}$.

Na verdade, em Kant também encontraremos a ideia de "publicidade". Esta funcionaria para legitimar determinada lei. Em seu opúsculo Zum ewigen Frieden, o, por assim dizer, "teste" de legitimidade ocorre mediante um teste de publicidade. Ligada ao já mencionado "uso público da razão", a ideia de publicidade será legitimadora. Daí Kant falar em um "princípio transcendental da publicidade (der transcendentale Prinzip der Publicität). Tal princípio determina o que é (ou não) politicamente justo. Assim, as leis devem passar pelo critério da publicidade: elas devem poder ser asseridas publicamente.

Não obstante, cabe notar que, embora seja leitor de autores tais quais Rousseau e Kant, tendo sido profundamente influenciado por estes, seu modelo está inscrito em outro contexto sociopolítico e histórico (bem como filosófico). Dito de outra forma, parece inquestionável que, em Habermas, há uma apropriação de elementos clássicos da filosofia prática que lhe precede. Aliás, não apenas isso: Habermas se apropria de diversos elementos de seu próprio tempo, para engendrar sua "ética do discurso". Autores da Sociologia, dos diversos ramos do pensamento filosófico, entre tantos, são arrolados por Habermas em uma tentativa de reapresentar e revisar drasticamente o projeto moderno no contexto contemporâneo, respondendo ao diagnóstico "pessimista" proposto pelos autores inicialmente citados. No entanto, Habermas revisa tais conceitos e temas à luz não apenas de seu próprio tempo, mas tendo em vista seu próprio projeto filosófico e sociológico, o qual é indubitavelmente sui generis, dentro da história da filosofia.

${ }^{84}$ Diferentemente da "vontade de todos" (volonté de tous), a qual seria uma soma de interesses particulares. Com efeito, a volonté de tous sempre se refere aos interesses privados.

${ }^{85}$ ROUSSEAU, 1996, p. 26. Tal concepção de liberdade será a essência do conceito kantiano de autonomia da vontade (Autonomie des Willens).

${ }^{86}$ Leia-se o capítulo I do Livro IV de "O contrato social". Nessa ideia de uma volonté générale encontramos um dos mais consistentes argumentos a favor de uma democracia deliberativa. 
De certa forma, Habermas representa, no contexto contemporâneo, uma das três grandes tentativas de dar conta dos problemas clássicos da filosofia prática, no contexto do pluralismo/multiculturalismo. ${ }^{87}$ Nesse sentido, importa levar em consideração o aspecto dialógico da concepção habermasiana de racionalidade. A ênfase dada ao aspecto intersubjetivo traz para si alguns elementos, tais quais os conceitos de "vontade geral", "publicidade", "uso público da razão" etc. Retomando tais conceitos, Habermas garante a legitimidade dos processos de deliberação prática (ética e política). Em acréscimo, ele garante, também, a ideia mesma de "emancipação", permitindo, ainda que em outros moldes (dentro do paradigma de uma razão dialógica), o processo de entendimento, o qual tem como medium, necessariamente, a linguagem. Trata-se, pois, de uma forma discursiva que tem como fundamento um elemento essencialmente normativo: a "ética do discurso" propriamente dita. Ela será, pois, essencial para uma fundamentação normativa da Öffentlichkeit.

FERRAZ, Carlos Adriano. Habermas: from the analisys of the Öffentlichkeit to the project of a "theory of communicative action". Trans/Form/Ação, (Marília); v.33, n.2, p.193-222, 2010.

ABSTRACT: This article intends to be an exposition of Habermas' Philosophy of Enlightenment. In this sense, we will present specially his earlier thought in order to establish his grounds, which implicates to start with the influences upon him (I. Kant, J.L. Austin, the "second" Wittgenstein, M. Weber, E. Husserl, K.O. Apel and so forth) as well as with his critic towards the first members of the Frankfurt School (specially against the pessimism of T. Adorno and M. Horkheimer on the power of reason to set us free). Finally, we will show how Habermas is an extension of the project of the Philosophy of Enlightenment, which makes him an example of Modern thought in the contemporary history of Philosophy.

KEYWORDS: Enlightenment. Ethics. Pragmatics.

\section{Referências}

ADORNO, Theodor.; HORKHEIMER, Max. Dialetik der Aufklärung: Philosophische Fragmente. Frankfurt am Main: Suhrkamp, 1984.

ALBERT, Hans. Traktat über kritische Vernunft. Stuttgart: UTB, 1991.

APEL, Karl Otto. Transformação da filosofia. São Paulo: Loyola, 2000.

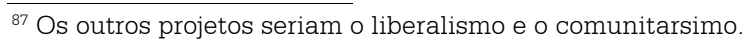


BARNES, Jonathan. The complete works of Aristotle. Princeton: Princeton University Press, 1995. v. 2.

AUSTIN, John. How to do things with words. Cambridge: Harvard University Press, 1975.

CHOMSKY, Noam. HERMAN, Edward. Manufacturating consent the political economy of the mass media. New York: Pantheon Books, 1988.

DUTRA, Delamar Volpato. Kant e Habermas: a reformulação discursiva da moral kantiana. Porto Alegre: EDIPUCRS, 2002.

Razão e consenso: uma introdução ao pensamento de Habermas. Pelotas: Editora da UFPel, 1993.

FREITAG, Barbara. A teoria crítica: ontem e hoje. São Paulo: Brasiliense, 1986.

FREITAG, Barbara; ROUANET, Sergio Paulo. Habermas: sociologia. São Paulo: Ática, 1980.

FUKUYAMA, Francis. O fim da história e o último homem. Rio de Janeiro: Rocco, 1992.

HABERMAS, Jürgen. A inclusão do outro. Estudos de teoria política. São Paulo: Loyola, 2004.

Consciência moral e agir comunicativo. Rio de Janeiro: Tempo Brasileiro, 2002

Direito e democracia: entre facticidade e validade. Rio de Janeiro: Tempo brasileiro, 2003. v. I.

Direito e democracia: entre facticidade e validade. Rio de Janeiro: Tempo brasileiro, 2003. v. II.

Pensamento pós-metafísico. Rio de Janeiro: Tempo brasileiro, 1989.

. Teoria y práxis: Estudios de filosofía social. Madrid: Tecnos, 2002.

Theory of communicative action. Boston: Beacon Press, 1987.

1995.

Kleine Politische Schriften. Frankfurt am Main: Suhrkamp Verlag,

Der philosophische Diskurs der Moderne: Zwölf Vorlesungen. Frankfurt am Main: Suhrkamp Verlag, 1985.

A ética da discussão e a questão da verdade. São Paulo: Martins Fontes, 2004. 
HABERMAS, Jürgen. Verdade e justificação: ensaios filosóficos. São Paulo: Edições Loyola, 2004.

Strukturwandel der Öffentlichkeit. Untersuchungen zu einer Kategorie der bürgerlichen Gesellschaft. Frankfurt am Main: Suhrkamp Verlag, 1999.

HORKHEIMER, Max. Eclipse da razão. Rio de Janeiro: Labor, 1976.

HUSSERL, Edmund. Die Krisis der europäischen Wissenschaften und die Transzendentale Phänomenologie. The Hague: M. Nijhoff, 1962.

KANT, Immanuel. Kants gesammelte schriften. Berlim: Walter de Gruyter, 1910-1966.

Grundlegung zur Metaphysik der Sitten. Stuttgart: Reclam, 2000.

Kritik der praktischen Vernunft. Stuttgart: Reclam, 1998.

MCCARTHY, Thomas. The Critical theory of Jürgen Habermas. Cambridge: MIT Press, 1981.

OLIVEIRA, Manfredo A. (Org.). Correntes fundamentais da ética contemporânea. Petrópolis: Vozes, 2000.

. Reviravolta lingüístico - pragmática na filosofia contemporânea. São Paulo: Loyola, 2001.

OLIVEIRA, Nythamar. Tractatus ethico-politicus. Porto Alegre: EDIPUCRS, 1999.

PEREIRA, Maria Helena da Rocha. Estudos de história da cultura clássica. Lisboa: Fundação Calouste Gulbenkian, 2002. v. II: Cultura Romana.

ROUANET, Sergio Paulo. Mal-estar na modernidade. São Paulo: Companhia das Letras, 2003.

As razões do Iluminismo. São Paulo: Companhia das Letras, 2004.

SIEBENEICHLER, Flávio Beno. Jürgen Habermas: razão comunicativa e emancipação. Rio de Janeiro: Tempo Brasileiro, 2003.

WEBER, Max. Die protestantische Ethik und der "Geist" des Kapitalismus. München: Verlag C. H. Beck, 2004

WITTGENSTEIN, Ludwig. Investigações filosóficas. São Paulo: Nova Cultural, 1999. 